\title{
Understanding the molecular basis of autism in a dish using hiPSCs-derived neurons from ASD patients
}

\author{
Chae-Seok Lim', Jung-eun Yang ${ }^{1}$, You-Kyung Lee², Kyungmin Lee ${ }^{3}$ Jin-A Lee ${ }^{2^{*}}$ and Bong-Kiun Kaang ${ }^{\text {** }}$
}

\begin{abstract}
Autism spectrum disorder (ASD) is a complex neurodevelopmental disorder characterized by deficits in social cognition, language development, and repetitive/restricted behaviors. Due to the complexity and heterogeneity of ASD and lack of a proper human cellular model system, the pathophysiological mechanism of ASD during the developmental process is largely unknown. However, recent progress in induced pluripotent stem cell (iPSC) technology as well as in vitro neural differentiation techniques have allowed us to functionally characterize neurons and analyze cortical development during neural differentiation. These technical advances will increase our understanding of the pathogenic mechanisms of heterogeneous ASD and help identify molecular biomarkers for patient stratification as well as personalized medicine. In this review, we summarize our current knowledge of iPSC generation, differentiation of specific neuronal subtypes from iPSCS, and phenotypic characterizations of human ASD patient-derived iPSC models. Finally, we discuss the current limitations of iPSC technology and future directions of ASD pathophysiology studies using iPSCs.
\end{abstract}

Keywords: Autism spectrum disorder (ASD), Cellular reprogramming, Induced pluripotent stem cells (iPSCs), Neural differentiation

\section{Introduction}

Autism spectrum disorder (ASD), which is characterized, in varying degrees, by difficulties in social interactions, verbal and nonverbal communications, and by repetitive behaviors, is complex disorders of brain development. The prevalence of ASD is estimated to range between $\sim 25$ and $\sim 110$ per 10,000 children $[1,2]$. There are no available cures for this devastating disease despite several current clinical trials. ASD is known to be highly heritable, as indicated by a study of monozygotic twins with a 70-90 \% concordance rate. In addition to its strong heritability, recent genetic studies have shown that ASD has hundreds of candidate genes with many different putatively disruptive variants [3, 4]. However, these are relatively rare genetic variations, each of which accounts for less than $1 \%$ of ASD cases [5]. Furthermore,

\footnotetext{
* Correspondence: leeja@hnu.kr; kaang@snu.ac.kr

${ }^{2}$ Department of Biological Sciences and Biotechnology, College of Life Science and NanoTechnology, Hannam University, Jeonmin-dong 461-6, Daejeon, Yuseong-gu 305-811, Korea

1 Department of Biological Sciences, College of Natural Sciences, Seoul National University, Gwanangno 599, Seoul, Gwanak-gu 151-747, Korea Full list of author information is available at the end of the article
}

ASD-associated genetic variations occur de novo in affected individuals and are sometimes inherited from normal parents, indicating either incomplete penetrance or other genetic modifications. Current studies have focused on the identification of common cellular pathways in order to account for connections between these various ASD candidate genes. Interestingly, to date, many synaptic proteins have been identified as ASD candidate genes, making it possible to study ASD pathogenesis using cellular and animal models [6-9].

To understand the underlying pathophysiological mechanisms of ASD, murine models have been generated using ASD candidate genes, including synaptic genes [10-12]. However, murine models are not always feasible and have several limitations for studying human neurodevelopment. Heterozygous mice with ASD mutation rarely develop ASD phenotypes unless the ASD genetic mutation is homozygous, which is exceptionally rare in ASD cases, indicating that other genetic modifications are required for developing ASD phenotypes or candidate genes have different functions in human neurons [13]. Furthermore, some human neocortical regions affected in ASD are not 
obtainable from mouse brain tissue, and brain development of mice does not perfectly reflect typical development of the human brain. Thus, understanding of neurodevelopmental disorders such as ASD has been lagged in the studies using animal models, including rodents or primate [14, 15]. Although primate models can overcome the limitations of rodent models such as differences in brain anatomy, response to drugs, or circuit connectivity between human and rodent brains, they recapitulate only limited behaviors such as simple social interactions or repetitive behaviors. Primate models could be difficult to apply for representation of a variety of human complex behavioral alterations shown in ASD patients to understand associated biological mechanisms and develop a knowledge-based therapy for ASD [15]. Although in vitro studies on neural differentiation using human embryonic stem cells (ESCs) have been suggested for understanding of human neurodevelopment, there remain numerous practical or ethical issues [16, 17].

To overcome these obstacles, induced pluripotent stem cells (iPSCs) technology, which allows the generation of personalized human neurons from ASD patients, has been used for studying the pathophysiology of ASD [18-20]. In this case, human neurodevelopment, which cannot be addressed in an animal model in vitro or in vivo, can be tracked using personalized iPSCs from ASD patients under an individual genetic background. Moreover, current gene engineering technology for human iPSCs using sequence-specific designed zinc finger nuclease (ZFN), transcription activator-like effector nuclease (TALENs), or CRISPR/Cas-9 has made disruption, mutation, or deletion of even large genomic fragments possible at a specific locus in the genome of hiPSCs and can be applied in ASD research for generation of isogenic iPSCs with gene correction and genetic disruption [21-26]. In addition, as an alternative method for customized disease modeling, direct conversion methods from human somatic cells into desired cell types such as neurons using lineage-specific factors have been suggested [27-29], although this method is still challenging and further stabilizing steps are needed for standardization of protocols.

In this review, we summarize (1) recent advances in generation of iPSCs, (2) current methods of neural differentiation from iPSCs, and (3) functional characterization of cellular disease phenotypes using recent ASD iPSC models and then discuss current limitations, future directions for modeling of ASD using iPSC technology, and potential applications $[26,30]$.

\section{Generation of iPSCs from human somatic cells: cellular reprogramming}

In 2006-2007, Takahashi and Yamanaka first showed that retroviral transfer of four transcription factors
(Oct4, Sox2, Klf4, and c-Myc) known as Yamanaka's factors is sufficient for cellular reprogramming of mouse or human skin fibroblasts into stem-cell like cells known as iPSCs, which have self-renewability and pluripotency $[31,32]$. Although there are concerns about subtle differences in transcriptomes, proteomes, and epigenomes between ESCs and iPSCs, iPSCs have been used in diverse research areas and clinical trials such as disease modeling, drug discovery, toxicology test, and regenerative medicine [26, 33] (Fig. 1). In recent years, iPSC reprogramming technology has undergone considerable improvements to overcome inefficient protocols and ensure functional derivatives for clinical application. Recent developments in iPSC technology using various somatic cell types include improved reprogramming methods using novel delivery systems such as nonintegrating viral and non-viral vectors as well as identification of alternative reprogramming factors or small molecules such as inhibitors of specific signaling or epigenetic modulators, which replace conventional reprogramming factors and facilitate reprogramming processes [33-35] (Table 2). A number of studies have reported detailed protocols for iPSC generation [35, 36]. Here, we summarize recent trends for generation of iPSCs from human somatic cells.

\section{Sources of somatic cells for reprogramming}

The first step in iPSC generation is obtaining appropriate human somatic cells from patient tissues $[37,38]$ after an accurate diagnosis of disease based on valid clinical processes. However, unlike other genetic or non-psychiatric disorders, the examiners should be far more careful when diagnosing ASD, including autism. Clinicians can usually consider two different categories of behavioral tests for the diagnosis of autistic individuals, observational reports (including questionnaires) such as the Autism Diagnostic Observation Schedule (ADOS) [39], Autism Diagnostic Interview-Revised (ADI-R) [40], Clinical Global Impression (CGI) Scale [41], Childhood Autism Rating Scale (CARS) [42, 43], Autism Behavior Checklist (ABC) [44, 45] and Social Responsiveness Scale (SRS) [46, 47] and the results of an aptitude test such as the Wechsler Adult Intelligence Scale (WAIS) [48] (Table 1).

The most common cell type as the starting material for reprogramming process is skin dermal fibroblasts [38]. However, since it is difficult to obtain skin biopsies from young children, especially those with autistic behavior, and the skin biopsy method using a punch is an invasive approach, it is important to obtain donor cells with high reprogramming capacity in a non-invasive way. As an alternative common cell source, peripheral blood cells are used for cellular reprogramming due to their non-invasive, easy, and routine accessibility in a clinic setting [38, 49, 50]. Recent efforts in iPSC generation have attempted to 


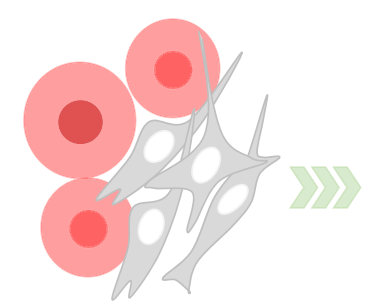

Somatic cells of ASD patients

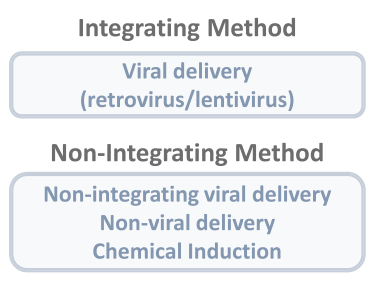

iPSC INDUCTION
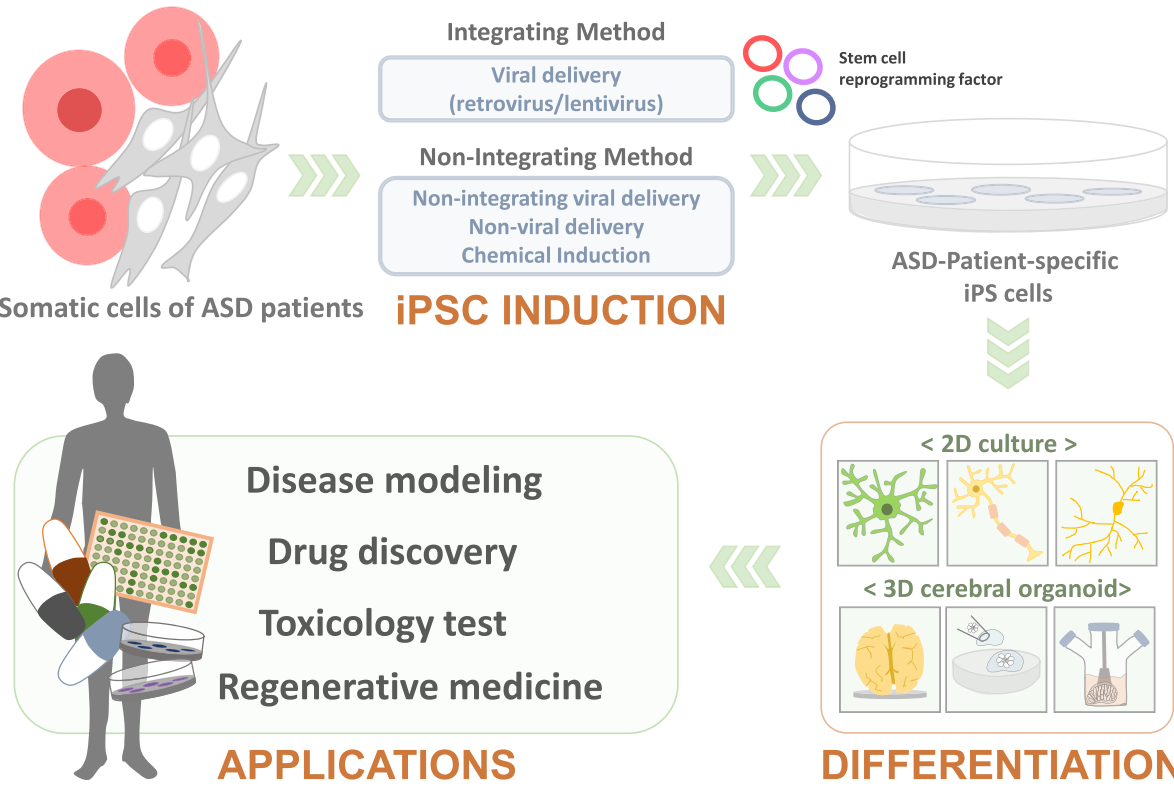

< 3D cerebral organoid>

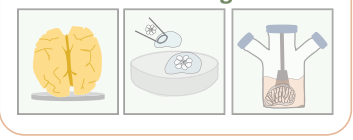

DIFFERENTIATION

Fig. 1 Generation and application of patient-specific iPSCs. Patient-specific iPSCs have been generated from human somatic cells such as skin fibroblasts or peripheral blood cells by viral, non-viral delivery, or chemical induction method. These customized iPSCs have been differentiated into desired neuronal cell types such as neurons, astrocytes, or microglia. Furthermore, iPSC-derived EB (embryoid body) could develop 3D cerebral organoids, which can recapitulate human cortical development. Therefore, patient-specific iPSC-derived neural cells or cerebral organoids could be used for diverse applications for disease modeling, drug discovery, toxicology test, and regenerative medicine

develop exfoliated renal epithelial cells from urine, buccal cells, cord blood-derived cells, or keratinocytes from hair cells as cell sources for reprogramming despite concerns about purification method, culture stability for long-term passaging, reproducibility, and efficiency for reprogramming [38]. Future advances in iPSC technology using human somatic cell types with easier access and handling, higher efficiency, and cost-effectiveness for successful reprogramming will allow development of more common customized medicines using iPSCs.

\section{Induction methods for cellular reprogramming: integrative/non-integrative}

Once somatic cells are taken from biopsies and cultured enough passages, they can be induced into stem cells using an appropriate reprogramming method. Many kinds of induction methods for cellular reprogramming have been reported depending on the delivery system of reprogramming factors or types of factors (ex, small molecules, inhibitors, etc.) as alternative reprogramming inducers [33]. The most common method is the introduction of

Table 1 Behavioral tests for the diagnosis of autistic individuals

\begin{tabular}{|c|c|c|c|}
\hline & Test methods & Description & References \\
\hline \multirow[t]{6}{*}{$\begin{array}{l}\text { Observational report } \\
\text { (including } \\
\text { questionnaires) }\end{array}$} & $\begin{array}{l}\text { Autism Diagnostic } \\
\text { Observation Schedule } \\
\text { (ADOS) }\end{array}$ & $\begin{array}{l}\text { A standardized assessment in terms of objective evaluation of autistic } \\
\text { social and communicative behavior symptoms }\end{array}$ & Lord et al. 1989 [39] \\
\hline & $\begin{array}{l}\text { Autism Diagnostic } \\
\text { Interview-Revised (ADI-R) }\end{array}$ & $\begin{array}{l}\text { An interview conducted with the parents of autistic individual to } \\
\text { cover autistic individual's full developmental history }\end{array}$ & Lord et al. 1994 [40] \\
\hline & $\begin{array}{l}\text { Clinical Global } \\
\text { Impression (CGl) Scale }\end{array}$ & $\begin{array}{l}\text { A three-item scale used to assess treatment response in patients with } \\
\text { mental disorders }\end{array}$ & Guy 1976 [41] \\
\hline & $\begin{array}{l}\text { Childhood Autism Rating } \\
\text { Scale (CARS) }\end{array}$ & $\begin{array}{l}\text { A score calculated by subjective observation of a child's behavior } \\
\text { across fifteen criteria }\end{array}$ & $\begin{array}{l}\text { Schopler et al. } 1980 \text { [42]; } \\
\text { Mayes et al. } 2012 \text { [43] }\end{array}$ \\
\hline & $\begin{array}{l}\text { Autism Behavior } \\
\text { Checklist (ABC) }\end{array}$ & $\begin{array}{l}\text { A 57-checklist of behavioral characteristics, which has been used for } \\
\text { diagnosis of autism }\end{array}$ & $\begin{array}{l}\text { Krug et al. } 1980[44] \\
\text { Volkmar et al. } 1988 \text { [45] }\end{array}$ \\
\hline & $\begin{array}{l}\text { Social Responsiveness } \\
\text { Scale (SRS) }\end{array}$ & $\begin{array}{l}\text { A quantitative measure of autistic traits completed by a caregiver } \\
\text { familiar with the autistic individuals within } 4-18 \text { year olds }\end{array}$ & $\begin{array}{l}\text { Constantino } 2002[46] \\
\text { Aldridge et al. } 2012[47]\end{array}$ \\
\hline Aptitude test & $\begin{array}{l}\text { Wechsler Adult } \\
\text { Intelligence Scale (WAIS) }\end{array}$ & $\begin{array}{l}\text { A form of IQ test designed to measure intelligence in adults and } \\
\text { older adolescents, which has separate verbal and non-verbal IQ } \\
\text { scores }\end{array}$ & Wechsler 1939 [48] \\
\hline
\end{tabular}


Table 2 Comparisons of reprogramming delivery system

\begin{tabular}{|c|c|c|c|c|}
\hline & Delivery system & Pros & Cons & References \\
\hline \multirow[t]{2}{*}{$\begin{array}{l}\text { Integrating } \\
\text { method }\end{array}$} & Retrovirus & High reprogramming efficiency ( 0.01-0.1\%) & $\begin{array}{l}\text { Possibility of oncogenesis; silencing of } \\
\text { functional genes }\end{array}$ & Takahashi and Yamanaka. 2006 [32] \\
\hline & Lentivirus & High reprogramming efficiency ( 0.01-0.1\%) & $\begin{array}{l}\text { Possibility of oncogenesis; silencing of } \\
\text { functional genes }\end{array}$ & Yu et al. 2007 [51] \\
\hline \multirow[t]{9}{*}{$\begin{array}{l}\text { Non- } \\
\text { integrating } \\
\text { method }\end{array}$} & Sendai virus & $\begin{array}{l}\text { No risk of altering the host genome; } \\
\text { high reprogramming efficiency }(\sim 1 \%) \text {; easy to } \\
\text { select iPSCs }\end{array}$ & $\begin{array}{l}\text { Stringent steps to remove the reprogrammed cells of } \\
\text { replicating virus; sensitivity of the viral RNA replicase }\end{array}$ & Fusaki et al. 2009 [55] \\
\hline & Adenovirus & Transient, high-level expression & $\begin{array}{l}\text { Low reprogramming efficiency }(0.0001-0.001 \%) \text {; } \\
\text { possibility of small pieces insertion of adenoviral } \\
\text { DNA; } 3 \text { out of } 13 \text { (or approximately } 23 \%) \text { were } \\
\text { tetraploid }\end{array}$ & Stadtfeld et al. 2008 [56] \\
\hline & $\begin{array}{l}\text { OriP/EBNA-based episomal } \\
\text { vector }\end{array}$ & $\begin{array}{l}\text { Unnecessary for viral packaging; gradual loss of } \\
\text { cellular EV without drug selection; relatively } \\
\text { high reprogramming efficiency of IRES2-mediated } \\
\text { expression( } 0.1 \%) \text {; further addition of c-Myc } \\
\text { and Klf4 improve the reprogramming } \\
\text { efficiency to over } 1 \%\end{array}$ & Unstable transfection efficiency & Yu et al. 2009 [168] \\
\hline & Piggy BAC transposons & $\begin{array}{l}\text { Technical simplification (use of effortless } \\
\text { plasmid DNA preparation and commercial } \\
\text { transfection products); no limited range of } \\
\text { somatic cell types for reprogramming; allow } \\
\text { the option of xeno-free hiPSC production; } \\
\text { accurate transgene removal through } \\
\text { transposase expression }\end{array}$ & $\begin{array}{l}\text { Labor intensive removal of multiple transposons; } \\
\text { more CNVs in early passage than in intermediate } \\
\text { passage; }\end{array}$ & $\begin{array}{l}\text { Woltjen et al. } 2009 \text { [59]; } \\
\text { Hussein et al. } 2011 \text { [162] }\end{array}$ \\
\hline & Cre-inducible/excisable lentivirus & $\begin{array}{l}\text { Minimize the risk of chromosomal } \\
\text { translocations; improve the developmental } \\
\text { potential and differentiation capacity }\end{array}$ & $\begin{array}{l}\text { Inefficient delivery of Cre; difficult to detect successful } \\
\text { Cre-recombeniation; result in mosaic colonies; leaves } \\
200 \text { bp of exogenous DNA }\end{array}$ & $\begin{array}{l}\text { Sommer et al. } 2010 \text { [58]; Soldner et al. } \\
2009 \text { [169]; Papapetrou et al. } 2011 \text { [170] }\end{array}$ \\
\hline & Minicircle DNA & $\begin{array}{l}\text { Free of foreign or chemical elements; requiring } \\
\text { only a single vector without the need for } \\
\text { subsequent drug selection, vector excision, } \\
\text { or the inclusion of oncogenes; FAD approved }\end{array}$ & Low reprogramming efficiency ( 0.005 \%) & Jia et al. 2010 [73]; Narsinh et al. 2011 [75] \\
\hline & Poly-arginine-tagged polypeptide & $\begin{array}{l}\text { No risk of altering the host genome; simpler } \\
\text { and faster approach than the genetic method }\end{array}$ & $\begin{array}{l}\text { Low reprogramming efficiency }(\sim 0.006 \%) \text {; } \\
\text { requires either chemical treatment or greater } \\
\text { than four rounds of treatment; expertise in protein } \\
\text { chemistry and handling }\end{array}$ & Zhou et al. 2009 [171]; Kim et al. 2009 [60] \\
\hline & RNA-modified synthetic mRNA & $\begin{array}{l}\text { Avoid the endogenous antiviral cell defense; } \\
\text { high efficiency of over } 2 \% \text {; resultant iPSC } \\
\text { colonies emerge as early as } 17 \text { days }\end{array}$ & Labor intensive repeated transfection & Warren et al. 2010 [61] \\
\hline & & $\begin{array}{l}\text { Non-immunogenic; cost-effective; easily } \\
\text { handled; }\end{array}$ & Relatively low and inconsistent efficiency & Hou et al. 2013 [80] \\
\hline
\end{tabular}


reprogramming factors into somatic cells via an integrating or non-integrating delivery system $[33,51,52]$.

\section{Integrating delivery system: retroviral/lentiviral vectors}

Integrating methods use viral vectors such as retroviral or lentiviral vectors with high efficiency of gene delivery, although viral vectors integrate into the host cell genome (reprogramming efficiency: 0.01-0.1\%). Generally, reprogramming factors are silenced after cellular reprogramming. However, genomic integration using viral vectors could induce reactivation of these genes, raising the possibility of oncogenesis in iPSC-derived cells or silencing of other functional genes after cellular reprogramming [53, 54]. Thus, many reprogramming methods without genomic integration have been described as a non-integrating approach, and some are commonly used for generation of iPSCs $[26,33,36,52]$.

\section{Non-integrating delivery system}

Regarding non-integrating approaches, non-integrating viral vectors (Sendai or Adeno virus), episomal vector, piggy BAC vector, Cre-inducible/excisable lentiviral vector, minicircle DNA, poly-arginine-tagged polypeptide (protein), RNA-modified synthetic mRNA, or microRNAs have been suggested for iPSC generation with diverse ranges of reprogramming efficiency (reprogramming efficiency: $0.001 \sim 4 \%$ ) [33, 35, 55-65]. Although each method has pros and cons (Table 2), non-integrating approaches generally have lower efficiency of cellular reprogramming compared to integrating lenti- or retroviral vectors. However, many efforts have attempted to improve the efficiency of cellular reprogramming.

1. Non-integrating transgene systems: Sendaiviral/ Adenoviral vector, episomal vector, integrative but excisable system (piggy Bac, Cre-loxP), and minicircle DNA

As one of the most attractive non-integrating viral vectors, Sendai virus with a negative-sense singlestranded RNA has been suggested as a potential clinical candidate since replication of transgenes occurs in the cytoplasm without possible genomic integration $[55,66,67]$. Although adenoviral vectors for cellular reprogramming have also been suggested as a non-integrating delivery system due to their transient and high expression of transgenes, reprogramming efficiency of human somatic cells is too low for common use ( 0.0002\%) [68]. For transient expression of reprogramming factors, compared to previous episomal vectors, more advanced OriP/ EBNA-based episomal vectors delivering combinational transgenes such as OCT3/4, SOX2, KLF4, L-MYC, LIN28, and shRNA for p53 have been described as a promising non-integrating approach for successful iPSC generation with acceptable reprogramming efficiency [57, 69]. Generation of integration-free iPSCs using either piggy Bac transposon or the Cre-loxP system has been also successful. Both systems are known to remove integrating transgenes from iPSCs after reprogramming, although there is a small risk of gene breaks near the insertion site $[58,59,70,71]$. Recently, minicircle DNA, which is a novel compact vector free of bacterial DNAs or human artificial chromosomes (HACs) with capacity for large gene insertion and stable episomal maintenance, have been used to successfully generate iPSCs, although their low reprogramming efficiency should be improved [72-75].

2. Non-integrating transgene-free systems: modified mRNA, protein, and chemicals

As for other transgene-free systems, modified mRNA, microRNA, or protein has been suggested as an attractive method for iPSC reprogramming in a clinical application due to more direct delivery of reprogramming factors without genomic integration. Synthetic mRNAs modified to avoid the endogenous antiviral cell defense system have more efficiently generated iPSCs with higher efficiency and faster iPSC induction compared to the retroviral system. However, labor-intensive steps such as repeated transfections of mRNAs should be improved. Reprogramming using microRNAs has also been successful with higher efficiency [62]. The protein transduction method using cell penetrating peptides is one of the safest methods for generating foot-print free iPSCs for use in a clinical purpose although reprogramming efficiency is very low $(\sim 0.0001 \%)$ [60]. In this system, technical challenges include generation of a large amount of functionally active and stable proteins as well as induction of reprogramming from diverse types of somatic cell sources via penetrating reprogramming proteins with simple treatment [76]. Alternatively, diverse chemical compounds capable of replacing initial Yamanaka's factors or other reprogramming factors have been investigated for iPSC generation due to their non-immunogenic, cost-effective, ease of use, reversible, cellpermeable, and standardized properties despite their inconsistent and low reprogramming efficiency. Small molecules that target signaling pathways such as transforming growth factor $\beta$ (TGF $\beta$ ) or epigenetic factors such as histone deacetylase have been proposed to generate iPSCs and improve reprogramming efficiency [76-79]. More recently, a cocktail of chemical compounds without any genetic factors successfully induced iPSCs from mouse somatic cells, raising the possibility of 
its application in the generation of iPSCs from human somatic cells [80]. More intensive screening for small molecules for cellular reprogramming and optimization is needed for efficient iPSC generation and its suitable application.

As mentioned above, a variety of promising methods with advantages and disadvantages have been proposed for the generation of patient-specific iPSCs (Table 2). Recent systematic evaluation of the most widely used techniques (Sendai-viral, episomal, or transfection of mRNA methods) for generating transgene-free hiPSCs have shown that significant differences between methods include aneuploidy rates, reprogramming efficiency, reliability, and workload, although they all result in high-quality iPSCs [81]. iPSC technology is rapidly advancing toward a transgene-free, small-molecule-based approach using diverse types of human somatic cells. Choice of reprogramming method will depend on the specific purposes for one's own iPSC research. For basic research or drug/toxicology tests using iPSCs, reprogramming methods generating iPSCs such as cost-effective integrating/nonintergrating methods with higher efficiency could be selected based on reprogramming efficiency, workload, time or economic feasibility, regardless of its safety issues. However, for clinical applications using iPSCs, safety issues such as caner progression, purity, or accessibility and feasibility using patient samples would be the most important concerns influencing selection of reprogramming methods, which would be nonintegrating/transgene-free methods.

\section{Generation of iPSC-derived neurons: neural differentiation}

In disease modeling using patient-specific iPSCs, the most important step is to differentiate iPSCs into desired cell types with high purity. Accumulating research on vertebrate neural development has enabled us to generate specific subtypes of human neurons or glial cells from human pluripotent stem cells (PSCs) by regulating developmentally relevant signaling pathways. During embryonic development, the neural plate (embryonic neuroectoderm) is firstly specified to the forebrain, subsequently to the midbrain/hindbrain, and then to the spinal cord by caudalization signals that include retinoic acid (RA). Similarly, human PSCs can be directed to differentiate into forebrain-like neurons by inhibiting Wingless/Int proteins (Wnt) and bone morphogenic protein (BMP) signaling [82], midbrain/hindbrain by sonic hedgehog $(\mathrm{SHH})$ and fibroblast growth factor 8 (FGF8) treatment $[83,84]$, and spinal cord by the action of RA in vitro $[85,86]$.

\section{Two-dimensional neural differentiation}

For disease modeling using iPSC-derived neurons, specific subtypes of neurons differentiated from iPSCs should be carefully chosen since the affected cell types and brain areas are different. A variety of subtype-specific neural differentiation protocols have been developed based on embryonic developmental studies. There are three general methods currently used for neural induction: (i) through embryoid body (EB) formation [85-90], (ii) cultivation on stromal (or mesenchymal) feeder cells [83, 91, 92], and (iii) direct conversion into neural lineage by lineage-specific factors [93-97] or small molecules [98-100] (Fig. 2).

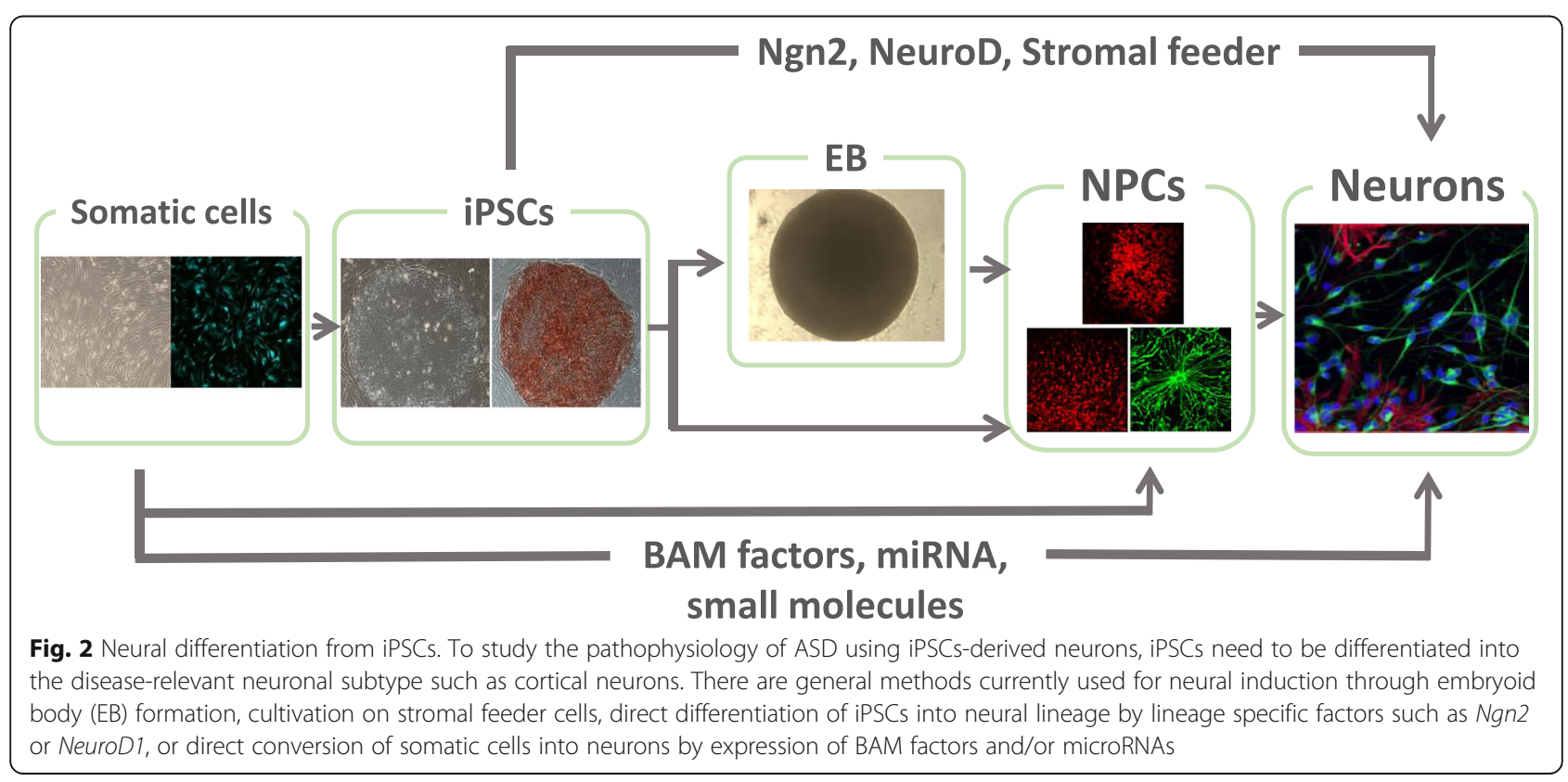


Table 3 Phenotypic analyses of ASD iPSC-derived neurons : Rett, Phelan-Mcdermid, Timothy, Fragile-X, and Angelman Syndromes

\begin{tabular}{|c|c|c|c|c|c|c|}
\hline Diseases & Related genes & $\begin{array}{l}\text { Neural } \\
\text { differentiation } \\
\text { methods }\end{array}$ & $\begin{array}{l}\text { Identity of } \\
\text { neurons }\end{array}$ & Electrophysiological proterties & Neurodevelopmental phenotypes & References \\
\hline Rett syndrome & $\begin{array}{l}\text { Methyl CpG binding } \\
\text { protein } 2 \text { (MECP2) }\end{array}$ & $\begin{array}{l}\text { Embryoid body } \\
\text { formation }\end{array}$ & $\begin{array}{l}\text { Gluramatergic } \\
\& \text { gabaergic } \\
\text { neurons }\end{array}$ & Reduced sEPSC and sIPSC & $\begin{array}{l}\text { Fewer synaptic conracts; reduced cell } \\
\text { soma size and dendritic branching } \\
\text { and spine density }\end{array}$ & $\begin{array}{l}\text { Marchetto et al. } 2010 \\
\text { [104]; Cheung et al. } 2011 \\
\text { [105]; Kim et al. } 2011 \\
\text { [106] }\end{array}$ \\
\hline $\begin{array}{l}\text { Phelan-McDermid } \\
\text { Syndrome (PMDS) } \\
\text { (22q13 deletion } \\
\text { syndrome) }\end{array}$ & Shank3 & $\begin{array}{l}\text { Dual smad } \\
\text { inhibition }\end{array}$ & $\begin{array}{l}\text { Forebrain } \\
\text { neurons }\end{array}$ & $\begin{array}{l}\text { Reduced excitatory synaptic } \\
\text { transmission }\end{array}$ & $\begin{array}{l}\text { Reduced glutamatergic receptors; } \\
\text { decreased number of synapses }\end{array}$ & $\begin{array}{l}\text { Shcheglovitov et al. } 2013 \\
\text { [117] }\end{array}$ \\
\hline $\begin{array}{l}\text { Timothy syndrome (A } \\
\text { member of the long } \\
\text { QT syndromes) }\end{array}$ & $\begin{array}{l}\text { CACNA1 (alpha-1 } \\
\text { subunit of the L-type } \\
\text { calcium channel } \\
\text { CaV1.2) }\end{array}$ & $\begin{array}{l}\text { Embryoid body } \\
\text { formation }\end{array}$ & $\begin{array}{l}\text { Cortical- } \\
\text { enriched } \\
\text { neuronal } \\
\text { populations }\end{array}$ & $\begin{array}{l}\text { Increase in the sustained intracellular } \\
\text { calcium rise following membrane } \\
\text { depolarization; wider action } \\
\text { potentials }\end{array}$ & $\begin{array}{l}\text { Decreased expression of lower } \\
\text { corticallayers-related genes; increases } \\
\text { in TH (tyrosine hydroxylase)-, norepinephrine- } \\
\text { and dopamine-positice cells; activity-dependent } \\
\text { dendrite retraction }\end{array}$ & $\begin{array}{l}\text { Pasca et al. } 2011 \text { [107]; } \\
\text { Krey et al. } 2013 \text { [108] }\end{array}$ \\
\hline Fragile $X$ syndrome & $\begin{array}{l}\text { Fragile } X \text { mental } \\
\text { retardation } 1 \text { (FMR1) }\end{array}$ & $\begin{array}{l}\text { Embryoid body } \\
\text { formation }\end{array}$ & $\begin{array}{l}\text { Tuj1-, MAP2- } \\
\text { or GFAP- } \\
\text { positive cells }\end{array}$ & $\begin{array}{l}\text { Poor spontaneous synaptic activity } \\
\text { and no glutamate reactivity }\end{array}$ & $\begin{array}{l}\text { Reduced neurite numbers and neurite lengths; } \\
\text { reduced PSD95 protein expression and reduced } \\
\text { synaptic punctadensity; poor neuronal maturation } \\
\text { and high gliogenic development }\end{array}$ & $\begin{array}{l}\text { Sheridan et al. } 2011 \\
\text { [109]; Telias et al. } 2013 \\
\text { [110] }\end{array}$ \\
\hline Angelman syndrome & $\begin{array}{l}\text { Ubiquitin protein } \\
\text { ligase E3A (UBE3A) }\end{array}$ & $\begin{array}{l}\text { Embryoid body } \\
\text { formation }\end{array}$ & $\begin{array}{l}\text { Tuj1-positive } \\
\text { cells }\end{array}$ & $\begin{array}{l}\text { Normal electrophysiological } \\
\text { properties }\end{array}$ & Intact imprinting of UBE3A & $\begin{array}{l}\text { Chamberlain et al. } \\
2010 \text { [111] }\end{array}$ \\
\hline
\end{tabular}




\section{EB-dependent differentiation}

In vivo neural tissue is differentiated from a germ layer called the ectoderm. Similarly, stem cells in vitro can develop three germ layers within aggregates called EBs, including ectoderm under appropriate stimulating conditions. Neural induction of stem cells can be commenced via EB formation by low basic fibroblast growth factor (bFGF) and subsequent induction of EBs into neural rosettes, which are a polarized organization of neuroepithelial cells and neural differentiation is achieved by a combination of specific sets of morphogens such as Wnt, SHH, BMPs, RA, and FGFs [85-88, 101-103]. Motor neurons having spinal lateral column phenotypes and midbrain dopaminergic neurons were differentiated from hESCs or hiPSCs with the EB formation method [84, 101, 102]. Most in vitro ASD-related disease modeling has been used this method (Table 3). For example, GABA ( $\gamma$-amino butyric acid) and vGlut1 (vesicular glutamate transpoter-1)-positive neurons were differentiated through EB formation [104, 105] and by blocking the BMP pathway [106] in in vitro Rett syndrome modeling. In addition, Dolmetsch group used this method to obtain vGlut1/2-, GAD65/67-positive and lower cortical layer-enriched neurons from syndrome patient-derived iPSC for investigation of Timothy syndrome [107, 108]. Tuj1-, MAP2- or GFAP-positive cells from Fragile-X syndrome patient-derived iPSCs $[109,110]$ and Tuj1-positive cells from Angelman syndrome patient-derived iPSCs [111] were also differentiated with this method. In vitro neuronal induction through EB formation, however, is time-consuming and requires multiple steps for generation of neural epithelial cells, neuronal progenitors, neuronal differentiation, and synaptic connection and maturation. Furthermore, it is hard to obtain a homogenous population of desired neuronal subtypes with high purity due to the difficulty in controlling specific lineage differentiation from EBs [112]. Therefore, the general neural induction method from EB formation was recently modified to improve induction efficiency and purity of desired neuronal cell types as well as reduce multiple steps for neural induction, although the neural induction method through EBs in vitro is ideal to mimic in vivo neural induction and neuronal differentiation. For example, inhibition of TGF $\beta$ and BMP pathways (dual SMAD inhibition: noggin and SB431542) have been used for efficient neural induction from stem cells without an EB formation step [113-116]. For in vitro modeling of Phelan-Mcdermid syndrome, Dolmetsch group used this method, with some modifications, to generate cortical neurons [117] (Table 3).

\section{Cultivation on stromal (or mesenchymal) feeder cells}

As the other neural induction method, stromal feederbased differentiation system, which is a serum-free system without the use of either RA or EBs, has been widely used, although the molecular basis of the neural-inducing activity of stromal cells remains unclear [83, 92]. An initial study suggested that stromal cells induce midbrain neuronal fate by default [91].

\section{Direct conversion: somatic or pluripotent stem cells to neurons/ somatic cells to neural progenitor or neural stem cells}

The other approach to generate human neurons is to convert human stem cells or somatic cells directly into neurons by defined specific factors [93-96] or small molecules [98-100]. Wernig's group reported a simpler and direct neural conversion method from human PSCs by forced expression of only a single transcription factor, Neurogenin 2 (Ngn2), NeuroD1 [97] or ASCL1 [118]. In human neurons induced via this method, functional synapses are rapidly formed within only 2 weeks after neural induction so that the time required to obtain mature human neurons in vitro is significantly reduced. Moreover, the most attractive point of using this method is to obtain a homogeneous cell population $(\sim 100 \%$ of cortical neurons) differentiated from hESCs and hiPSCs [97]. As an alternative approach to generate induced neurons, a combination of three transcription factors BRN2 (also called Pou3f2), ASCL1 (also known as $M A S H 1$ ), and MYT1L (so called BAM factors) - could convert adult mouse fibroblasts directly into functional neurons without iPSC generation [93, 119]. The neurons generated by this method are also able to fire spontaneous action potentials and make functional synapses within as early as 2 weeks after induction in vitro. The same three transcription factors also could differentiate human stem cells and fibroblasts into neurons when combined with a transcription factor, NeuroD1 [94], microRNAs [95, 120], or small molecules [121]. In addition, very recently, it has been reported that only small-molecule cocktails were sufficient to directly convert mouse and human fibroblasts to functional neurons without exogenous genetic factors [98-100]. Likewise, rapid generation of specific subtypes of neurons directly from somatic cells makes this method an effective strategy for in vitro ASD modeling. However, a key limitation of this method is that a large number of fibroblasts might be required for reliable experiments due to their low reprogramming efficiency (at most 10-30\%), and skin biopsy cannot be conducted many times on a single patient. Therefore, in some cases, it would be desirable to convert fibroblasts into self-renewing multipotent neural progenitor cells (NPCs) or neural stem cells (NSCs), which enables us to overcome the limitations associated with low reprogramming efficiency and thereby perform high-throughput drug screening. Kim et al. [122] described the generation of NPCs from mouse fibroblasts by transient expression of Yamanaka's 
factors (Oct4, Sox2, Klf4, and c-Myc), followed by culturing in neural induction media. However, NPCs generated by this method could be expanded for only a few passages. Thier et al. [123] have generated induced NSCs with the same classical factors (Oct4, Sox2, Klf4 and c-Myc) by strictly limiting Oct4 expression and optimizing culture conditions. In addition, forced expression of four transcription factors (BRN4/Pou3f4, SOX2, KLF4 and c-MYC) [124] or even a single transcription factor SOX2 [125] could also directly convert mouse or human fibroblasts into NSCs without generating a pluripotent cell state. Therefore, this direct conversion method is considered a promising method for preventing teratoma formation, which is a disadvantage of iPSCs for regenerative medicine, as well as for greatly improving low conversion efficiency from fibroblasts to neurons [126].
To study the pathophysiology of ASD using iPSCderived neurons in vitro, it is important to obtain desired homogeneous neurons associated with ASD, as mentioned above. Cortical neurons have been suggested to be appropriate cell types since potential mechanisms underlying ASD include defects in cortical connectivity and neural migration to the cerebral cortex [127]. Moreover, despite the heterogeneity of ASD, common pathways involved in synaptic development and plasticity have been proposed to be deregulated in ASD. Thus, to study developmental synaptopathy in ASD, among several protocols for neural induction, rapid generation of human cortical neurons using defined factors could be one of the best strategies for in vitro ASD modeling due to their high induction efficiency of homogenous neuronal subtype and short induction time. However, if human neurons are directly generated from stem cells or somatic cells for modeling

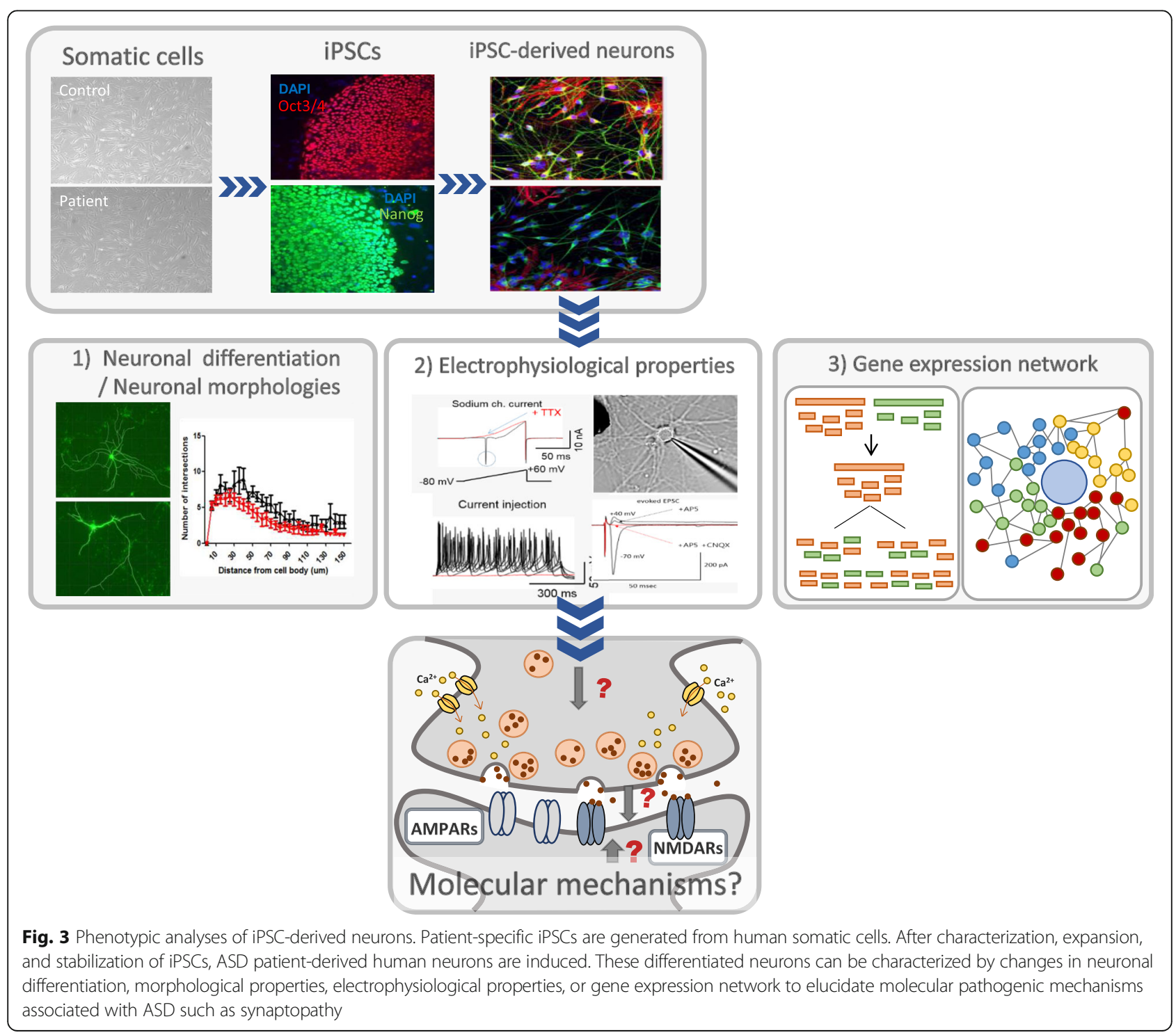


neurodevelopmental disorders such as ASD, it might be difficult to detect developmental phenotypes during neural differentiation. Furthermore, continuous forced expression of defined factors could also mask disease phenotypes [20,128]. Therefore, differentiation efficiency or stability of human neurons induced by defined factors should be improved, and comparable systematic analysis of neuronal properties such as gene expression, electrical properties, or synaptic connections in human neurons differentiated either through EB formation or by defined factors needs to be carried out.

\section{Three-dimensional neural differentiation: cerebral organoids} Magnetic resonance imaging (MRI) studies and postmortem analysis of individual patients with ASD have consistently demonstrated anatomical abnormalities in several brain regions, which cannot be recapitulated by two-dimensional (2D) iPSC-derived neuronal culture [129]. An iPSC-derived three-dimensional (3D) culture system termed cerebral organoid has been developed [130, 131]. Cerebral organoids, which develop through intrinsic self-organizing properties, can be generated from EBs grown initially in ESC medium with low bFGF and Rho kinase (ROCK) inhibitor [131], and they have been shown to recapitulate the complex interplay of different regions and structures of the brain [130]. Therefore, 3D cerebral organoids derived from ASD patientspecific iPSCs would be the best in vitro model to uncover defects in cortical connectivity and neuronal migration of ASD. Indeed, Mariani et al. recently generated idiopathic ASD patient's iPSC-derived brain organoids and showed increased production of inhibitory neurons by increased FOXG1 gene expression [132]. However, more standardized protocols need to be developed, and further characterization and identification of neuronal cell types in specific regions of cerebral organoids should be carried out to study cortical development and for disease modeling of ASD patients.

\section{Analyses of human iPSC-derived neurons}

To use iPSC technology in modeling of various neurodevelopmental disorders including ASD in vitro, it is important to characterize disease phenotypes in diseasespecific iPSC-derived neurons and validate well-known disease phenotypes to determine whether or not iPSCderived cellular disease models could recapitulate disease phenotypes in mouse models and human patients. Because of this reason, ASD research using this technology primarily includes several studies on monogenic cases, such as Rett Syndrome, Fragile X Syndrome, and Timothy Syndrome [104-108, 133, 134]. However, these initial studies on cellular disease phenotypes in iPSC-derived neurons from monogenic cases of ASD could be directed towards the identification of disease-relevant cellular characterization in both monogenic and idiopathic forms of ASD with high heterogeneity. In this section, we describe what phenotypic analyses of human iPSC-derived neurons can be performed to characterize and validate iPSC-derived cellular disease models.

There are general phenotypic analyses of human neurons derived from iPSCs based on (i) neural differentiation and neuronal morphologies (neurite outgrowth, synapse structure), (ii) electrophysiological properties (basic electrical properties, synaptic properties), and (iii) gene expression network (transcriptome analysis) (Fig. 3).

\section{Neural differentiation and neuronal morphologies: neurite outgrowth/synapse structure}

Fully differentiated neuronal cells have a distinct morphology, including distinct polarity, and extend one axon and dendritic arbors from their cell body. Therefore, the earliest phenotypes of hiPSC-derived neurons are morphological changes such as neural differentiation, neurite/axon/dendritic growth (number or length of neurite process), and synapse formation, which can be used for analysis of disease-relevant morphological phenotypic changes. During the early stages of neurogenesis, newborn neurons are NeuNpositive [135] and PSA-NCAM-positive [136]. These markers, together with neuronal cytoskeletal proteins Tuj1, Tau, and MAP2, can be used for measuring neural maturation efficiency or morphological changes in ASD iPSC-derived neurons [137]. Specific neuronal gene expression as a subtype-specific marker can be also used to confirm neuronal identities. For example, glutamatergic neurons can express vGlut1 and vGlut2 [138], GABAergic neurons express GAD65/67 [139], and mature dopaminergic neurons express tyrosine hydroxylase (TH) [140].

Moreover, disease phenotypes such as cortical connectivity and neural migration in ASD-derived cerebral organoids would be characterized using various markers for a specific subtype of neurons in cortical regions. In rodents, cortical glutamatergic neurons can be defined by their expression of different transcription factors [17, 141-148]. Layer 6 corticothalamic projection neurons are Tbr1-positive [144, 145], layer 5 subcortical projection neurons are Ctip2-positive [143], layers 2-4 neurons are Cux1/2-positive [146], and layers 2-4 callosal projection neurons are Satb2-positive [147, 148].

\section{Electrophysiological properties}

Electrophysiological characterization for basic electrical properties such as membrane potential, generation of action potentials by current injection, and synaptic properties such as appearance of spontaneous synaptic events can be applied to verify and characterize hiPSC-derived neurons. As neurons mature, resting membrane potentials 
$\left(\mathrm{V}_{\mathrm{m}}\right)$ become negative (more hyperpolarized) and capacitance $\left(\mathrm{C}_{\mathrm{m}}\right)$ increases due to increased branch numbers, leading to increased cell volume. In contrast, input resistance $\left(\mathrm{R}_{\mathrm{i}}\right)$ decreases as channel protein expression increases. In addition, action potential-like responses induced by depolarization are resemble the mature shape of the action potential. Since neurons are able to make synapses with other neurons, synaptic properties could be also characterized as a cellular phenotype in iPSC-derived disease models. hiPSC-derived neurons from many syndromic ASD patients have defects in synaptic connectivity such as spontaneous excitatory and inhibitory currents [104], AMPA/NMDA current ratio [117], as well as intrinsic neuronal excitability [107] (Table 3).

\section{Gene expression network}

Similar to the phenotypic analyses, transcriptional changes based on gene expression network could be characterized in ASD iPSC-derived neurons. This analysis based on a systems biology approach allows us to understand alterations of the gene network involved in neural development and functions associated with ASD. Recent studies using genome-wide weighted co-expression network analysis (GWCNA) on Timothy Syndrome (TS)-derived neural cells have shown that altered $\mathrm{Ca}^{2+}$ signaling in TS patients leads to dysregulation of calcium-dependent transcriptional regulators such as NFAT, MEF2, CREB, and FOXO as well as its downstream signals [149]. Gene expression analysis of hiPSC-derived neurons carrying copy number variants of chromosome 15q11-q13.1 using RNA-Seq has revealed that common neuronal pathways may be disrupted in both Angelman and Dup15q syndromes [150].

\section{Phenotypic analyses of ASD iPSC-derived neurons: Rett, Phelan-Mcdermid, Timothy, Fragile-X, and Angelman Syndromes}

In Rett syndrome (RTT), a neurodevelopmental ASD due primarily to mutations in the methyl-CpG binding protein 2 (MECP2) gene, hiPSC-derived neural cells show reduced soma size, dendrite spine density, differentiation, and reduced spontaneous $\mathrm{Ca}^{2+}$ transient frequency in neurons and premature astroglial [104-106, 151, 152], as shown in human postmortem analyses. In addition, reduced frequency and amplitude of mEPSCs and mIPSCs [104] have been observed in RTT hiPSC-derived neurons, suggesting fewer production of synapses and reduction of postsynaptic receptors [104]. HiPSC-derived cellular disease models could be also used as a system for screening candidates for disease therapy since iPSC-derived neurons can recapitulate disease phenotypes in human and mouse models. Indeed, insulin-like growth factor 1 (IGF-1) was applied to hiPSC-derived RTT neurons and showed rescue of reduction in excitatory glutamatergic synaptic connections [104] as in mouse models of RTT, in which reduced excitatory synaptic connections in RTT neurons could be reversed by IGF-1 application [153]. IGF-1 is currently in clinical trials for RTT.

hiPSC-derived neurons from Phelan-Mcdermid syndrome (PMDS) patients, carrying a deletion of Shank3 protein, have significant deficits in excitatory synaptic transmission [117]. These deficits were rescued by either wild-type Shank3 expression or IGF-1 treatment as in hiPSC-derived RTT neurons [117], suggesting that a common signaling pathway might be involved in the pathophysiology of ASD. Therefore, hiPSC-derived neurons could be useful as a potential drug-screening platform, as mentioned above.

Timothy syndrome (TS) is caused by a point mutation in the voltage-gated calcium channel encoded by the CACNA1 gene. TS patients iPSC-derived neurons show wider action potentials, suggesting a loss of $\mathrm{CaV}_{1.2}$ channel inactivation, abnormal expression of tyrosine hydroxylase $(\mathrm{TH})$, and increased production of norepinephrine and dopamine [107]. Activity-dependent dendritic retraction by RhoA activation independent of $\mathrm{Ca}^{2+}$ influx through $\mathrm{CaV}_{1.2}$ has also been reported in TS iPSC-derived neurons [108].

Neurons from Fragile-X syndrome patients-derived hiPSCs show reduced neurite numbers and lengths [109], poor spontaneous synaptic activity, and lack reactivity to glutamate [110].

In Angelman Syndrome (AS), which is caused by reduced expression of the maternal copy of the Ube3A gene in CNS, patient-derived iPSCs show retained genomic imprinting. In addition, electrophysiological recordings have detected AMPA receptor-mediated spontaneous activity in AS iPSC-derived mature neurons, suggesting that normal functional neurons can be generated from AS iPSCs [111].

Recently, Muotri's group have generated an iPSC model of a nonsyndromic ASD patient carrying a de novo balanced translocation transient receptor potential channel 6 (TRPC6) [154]. TRPC6-mutant iPSC-derived neurons showed reduced neuronal arborization, fewer dendritic spines and synapses, and impaired calcium dynamics [154]. They also found that MECP2 occupied the TRPC6 promoter region and regulated TRPC6 expression, raising the possibility of interactions among common pathways affected in nonsyndromic and syndromic ASD.

\section{Conclusions}

\section{Perspectives: limitations and future directions} iPSC research

Despite numerous studies underlying the pathophysiological mechanism of ASD using iPSCs, several concerns should be addressed before iPSC research $[155,156]$. Current advances in iPSC technology have allowed us to successfully derive patient-specific iPSCs regardless of their reprogramming methods. Furthermore, a recent 
study showed that a modular, robotic platform for iPSC reprogramming enabled automated, high-throughput conversion of skin fibroblasts into iPSCs and their characterization/differentiation with minimal manual intervention [157]. However, it still remains unknown how to obtain qualified iPSCs and improve the quality of patient-specific iPSCs under suitable and cost-effective cultivation conditions for diverse applications, including disease modeling, drug screening, and customized therapy. As mentioned above, although iPSCs are similar to ESCs in terms of pluripotent marker gene expression, self-renewal potency, differentiation potential, and their morphology, they are not identical. Recent extensive genetic analysis using high-throughput sequencing technology or generation of single-nucleotide genome-wide maps of DNA methylation has demonstrated the genomic/epigenetic differences between iPSCs and ESCs. However, the functional consequences of their differences in vitro or in vivo are largely unknown. Moreover, iPSCs and ESCs show a wide range of clonal variations in terms of proliferation and differentiation potential. Furthermore, iPSCs derived from even the same parental somatic cells have different potential in terms of expansion or differentiation [158-160]. Considerable somatic coding mutations occurring in hiPSC lines have also been reported by extensive exome analysis [161]. The other main concern is the instability of iPSCs during passaging of clones. It has been reported that early passages of iPSCs display de novo copy number variations (CNV) during the reprogramming process [162]. Thus, to obtain a more reliable outcome from iPSC research, generation of isogenic iPSCs using recent gene engineering technology or by establishment of at least 2-3 iPSC clones from the same parental somatic cells has been suggested. However, it remains unknown how these genetic/epigenetic alterations occur during reprogramming or expansion of iPSCs as well as how these alterations can be managed for iPSC generation or its application. Further, it remains unknown whether there is any reprogramming method to reduce or exclude these possible alterations as well as how to select the qualified iPSC clone from a variety of iPSC lines. To address these questions, further intensive works at the genetic/epigenetic/cellular levels are needed, and in vivo functional characterization of iPSC-derived cells needs to be carried out. Thus, the most important issue in iPSC generation is to establish more stable and standard protocols for safer and easier iPSC generation in diverse applications.

Although there are some differences between ESC and iPSCs, iPSCs are still the most promising choice for modeling with human cells. In mouse, iPSCs have the same potential as ESCs because a mature organism can be generated from iPSCs via blastocyst injection or tetraploid complementation [163]. Although human iPSCs cannot be tested using these embryological methods owing to ethical issues and hiPSCs appear to be 'primed' PSCs as mouse Epi-stem cells, naïve human PSCs might be used as another human cellular model.

\section{Current limitations of studies on pathophysiology using ASD iPSC-derived neurons}

Besides iPSC line-to-line variations, limitations of studying ASD with hiPSC-derived neurons include phenotypic variations between neurons derived from the same iPSCs, which are based on differences between individual hiPSC-derived neurons from even a single patient due to heterogeneity of neuronal subtypes differentiated from each iPSC line [164] even with well-defined differentiation protocols. In addition, different differentiation methods such as usage of small molecules or genes, EB formation vs. monolayer culture, concentration of small molecules and growth factors, differentiation time can also generate variations in the neuronal population. The use of cell type-specific promoters to drive expression of fluorescent markers for purification by cell sorting or identification of desired cell types would be a powerful tool to reduce variation. The surrounding environment of cells may also significantly affect the phenotypes. For example, the presence of neural progenitor cells in neuronal culture could mask disease-associated phenotypes by continuous production of newborn neurons [112]. Therefore, to obtain reliable data using hiPSC-derived neurons from ASD patients, each experiment should be performed with multiple neuronal differentiation protocols from at least two or three independent hiPSC lines with the same mutation from multiple patients. In addition, forced expression of a transcription factor like Ngn2 would be a good method to overcome the above described issues, in which almost $\sim 100 \%$ of cortical neurons at a similar maturation stage could be generated, and the neurons showed their synaptic phenotypes as early as 3 weeks after forced Ngn2 expression [97].

As mentioned above, widespread genetic variations could exist between iPSC lines themselves derived from unrelated individuals. Therefore, genetically related family memberderived control lines could possibly be used to reduce variability of phenotypes, although it would not completely remove the possibility that even a single genetic difference could potentially affect observable phenotypes. Another possible way is to use gene correction methods since the ideal controls would be those that have the same genetic background except only the specific genetic defect found in the patient. Many well-known syndromic ASD-related genetic variants can be modeled with "isogenic" cell lines, where a patient-derived iPSC line could be gene-corrected using ZFNs, TALENs, or CRISPR-Cas9 technologies, reverting a mutant line to wild-type or vice versa $[165,166]$. 
As iPSCs are an in vitro culture system, they lack many characteristics of a developing and mature brain physiology in vivo. Therefore, it is difficult to study neuronal circuitry and organization using iPSC-derived neurons under 2D conditions, particularly when investigating phenotypes unique to specific neuronal circuits of the adult brain. One way to avoid these problems is to xenograft iPSC-derived neural progenitor cells (NPCs) into embryonic rodent brains to allow them to integrate into developing neural networks and mature in vivo. Cerebral "organoids" [130] is another possible way to study disease phenotypes in a specific cell type or group of cell fates in the context of 3D model of human neurodevelopment [130, 167], as reported by Mariani et al. [132].

In summary, we can generate hiPSC-derived neurons from fibroblasts and other somatic cells of ASD patients to investigate alterations of neuronal connectivity, synaptic maturation, and functions. In addition, direct conversion of fibroblasts from ASD patients into neurons or $\mathrm{NPC} / \mathrm{NSCs}$ would be used as an alternative in vitro model of ASD in the near future. However, we need to realize that hiPSC-based studies of ASD pathophysiology will not completely replace human postmortem and mouse genetic studies. Nevertheless, disease modeling with hiPSC-derived neurons combined with their comprehensive molecular and functional characterization will be a new and strong tool for understanding complex neurodevelopmental disorder, ASD.

\begin{abstract}
Abbreviations
ASD: Autism spectrum disorder; iPSC: induced pluripotent stem cell; ESCs: Embryonic stem cells; PSCs: Pluripotent stem cells; ZFN: Zinc finger nuclease; TALEN: Transcription activator-like effector nuclease; HAC: Human artificial chromosome; Wnt: Wingless/Int proteins; BMP: Bone morphogenic protein; SHH: Sonic hedgehog; FGF8: Fibroblast growth factor 8; RA: Retinoic acid; EB: Embryoid body; bFGF: basic fibroblast growth factor; TGF $\beta$ : Transforming growth factor $\beta_{;}$Ngn2: Neurogenin 2; MRI: magnetic resonance imaging; 2D: Two-dimensional; 3D: Three-dimensional; RTT: Rett syndrome; MECP2: Methyl-CpG binding protein 2; TS: Timothy syndrome; TH: Tyrosine hydroxylase; TRPC6: Transient receptor potential channel 6; CNV: Copy number variation.
\end{abstract}

\section{Competing interests}

The authors declare that they have no competing interests.

\section{Authors' contributions}

$\mathrm{BK}, \mathrm{CS}, \mathrm{JE}, \mathrm{KM}$ and JA organized and wrote the manuscript. YK helped to draft tables and figures. All authors read and approved the final manuscript.

\section{Acknowledgements}

We apologize to colleagues whose work could not be cited due to space limitations. This work was supported by National Honor Scientist Program of Korea (2012R1A3A1050385). Jin-A Lee was supported by the Basic Science Research Program through the NRF (2014R1A1A4A01003859).

\footnotetext{
Author details

${ }^{1}$ Department of Biological Sciences, College of Natural Sciences, Seoul National University, Gwanangno 599, Seoul, Gwanak-gu 151-747, Korea. ${ }^{2}$ Department of Biological Sciences and Biotechnology, College of Life Science and NanoTechnology, Hannam University, Jeonmin-dong 461-6, Daejeon, Yuseong-gu 305-811, Korea. ${ }^{3}$ Department of Anatomy, Kyungpook
}

National University Graduate School of Medicine, Dongin-dong 2-101, Daegu, Jung-gu 700-422, Korea.

Received: 27 May 2015 Accepted: 11 September 2015

Published online: 30 September 2015

\section{References}

1. Baird G, Simonoff E, Pickles A, Chandler S, Loucas T, Meldrum D, et al. Prevalence of disorders of the autism spectrum in a population cohort of children in South Thames: the Special Needs and Autism Project (SNAP). Lancet. 2006;368:210-5.

2. Kogan MD, Blumberg SJ, Schieve LA, Boyle CA, Perrin JM, Ghandour RM, et al. Prevalence of parent-reported diagnosis of autism spectrum disorder among children in the US, 2007. Pediatrics. 2009;124:1395-403.

3. Pinto D, Delaby E, Merico D, Barbosa M, Merikangas A, Klei L, et al. Convergence of genes and cellular pathways dysregulated in autism spectrum disorders. Am J Hum Genet. 2014:94:677-94.

4. Jeremy Willsey A, State MW. Autism spectrum disorders: from genes to neurobiology. Curr Opin Neurobiol. 2015;30C:92-9.

5. Devlin B, Scherer SW. Genetic architecture in autism spectrum disorder. Curr Opin Genet Dev. 2012;22:229-37.

6. Zoghbi HY, Bear MF. Synaptic dysfunction in neurodevelopmental disorders associated with autism and intellectual disabilities. Cold Spring Harb Perspect Biol. 2012:4:3.

7. An JY, Cristino AS, Zhao Q, Edson J, Williams SM, Ravine D, et al. Towards a molecular characterization of autism spectrum disorders: an exome sequencing and systems approach. Transl Psychiatry. 2014;4:e394.

8. Ebrahimi-Fakhari D, Sahin M. Autism and the synapse: emerging mechanisms and mechanism-based therapies. Curr Opin Neurol. 2015;28:91-102.

9. Bourgeron T. From the genetic architecture to synaptic plasticity in autism spectrum disorder. Nat Rev Neurosci. 2015;16:551-63.

10. Won H, Lee HR, Gee HY, Mah W, Kim Jl, Lee J, et al. Autistic-like social behaviour in Shank2-mutant mice improved by restoring NMDA receptor function. Nature. 2012;486:261-5.

11. Banerjee S, Riordan M, Bhat MA. Genetic aspects of autism spectrum disorders: insights from animal models. Front Cell Neurosci. 2014;8:58.

12. Moy SS, Nadler JJ. Advances in behavioral genetics: mouse models of autism. Mol Psychiatry. 2008;13:4-26.

13. Ey E, Leblond CS, Bourgeron T. Behavioral profiles of mouse models for autism spectrum disorders. Autism Res. 2011;4:5-16.

14. Tordjman $S$, Drapier D, Bonnot O, Graignic R, Fortes $S$, Cohen D, et al. Animal models relevant to schizophrenia and autism: validity and limitations. Behav Genet. 2007;37:61-78.

15. Tania M, Khan MA, Xia K. Recent advances in animal model experimentation in autism research. Acta Neuropsychiatr. 2014;26:264-71.

16. Thomson JA, Itskovitz-Eldor J, Shapiro SS, Waknitz MA, Swiergiel JJ, Marshall VS, et al. Embryonic stem cell lines derived from human blastocysts. Science (New York, NY). 1998;282:1145-7.

17. Shi Y, Kirwan P, Smith J, Robinson HP, Livesey FJ. Human cerebral cortex development from pluripotent stem cells to functional excitatory synapses. Nat Neurosci. 2012;15(477-486):S471.

18. Liu EY, Scott CT. Great expectations: autism spectrum disorder and induced pluripotent stem cell technologies. Stem Cell Rev. 2014;10:145-50.

19. Kim DS, Ross PJ, Zaslavsky K, Ellis J. Optimizing neuronal differentiation from induced pluripotent stem cells to model ASD. Front Cell Neurosci. 2014;8:109.

20. Prilutsky D, Palmer NP, Smedemark-Margulies N, Schlaeger TM, Margulies DM, Kohane IS. IPSC-derived neurons as a higher-throughput readout for autism: promises and pitfalls. Trends Mol Med. 2014;20:91-104.

21. Ding Q, Lee YK, Schaefer EA, Peters DT, Veres A, Kim K, et al. A TALEN genome-editing system for generating human stem cell-based disease models. Cell Stem Cell. 2013;12:238-51.

22. Lombardo A, Genovese P, Beausejour CM, Colleoni S, Lee YL, Kim KA, et al. Gene editing in human stem cells using zinc finger nucleases and integrasedefective lentiviral vector delivery. Nat Biotechnol. 2007;25:1298-306.

23. Kim Y, Kweon J, Kim A, Chon JK, Yoo JY, Kim HJ, et al. A library of TAL effector nucleases spanning the human genome. Nat Biotechnol. 2013;31:251-8.

24. Smith C, Abalde-Atristain L, He C, Brodsky BR, Braunstein EM, Chaudhari P, et al. Efficient and allele-specific genome editing of disease loci in human iPSCs. Molecular therapy : the journal of the American Society of Gene Therapy. 2015;23:570-7. 
25. Chiba K, Hockemeyer D. Genome editing in human pluripotent stem cells using site-specific nucleases. Methods in molecular biology (Clifton, NJ). 2015;1239:267-80

26. Okano H, Yamanaka S. iPS cell technologies: significance and applications to CNS regeneration and disease. Mol Brain. 2014;7:22

27. Velasco I, Salazar P, Giorgetti A, Ramos-Mejia V, Castano J, Romero-Moya D, et al. Concise review: generation of neurons from somatic cells of healthy individuals and neurological patients through induced pluripotency or direct conversion. Stem cells (Dayton, Ohio). 2014;32:2811-7.

28. $\mathrm{Xu} \mathrm{J,} \mathrm{Du} \mathrm{Y,} \mathrm{Deng} \mathrm{H.} \mathrm{Direct} \mathrm{Lineage} \mathrm{Reprogramming:} \mathrm{Strategies,}$ Mechanisms, and Applications. Cell Stem Cell. 2015;16:119-34.

29. Kim J, Ambasudhan R, Ding S. Direct lineage reprogramming to neural cells. Curr Opin Neurobiol. 2012;22:778-84.

30. Okano H, Nakamura M, Yoshida K, Okada Y, Tsuji O, Nori S, et al. Steps toward safe cell therapy using induced pluripotent stem cells. Circ Res. 2013;112:523-33.

31. Takahashi K, Tanabe K, Ohnuki M, Narita M, Ichisaka T, Tomoda K, et al. Induction of pluripotent stem cells from adult human fibroblasts by defined factors. Cell. 2007;131:861-72

32. Takahashi K, Yamanaka S. Induction of pluripotent stem cells from mouse embryonic and adult fibroblast cultures by defined factors. Cell. 2006;126:663-76.

33. Singh VK, Kalsan M, Kumar N, Saini A, Chandra R. Induced pluripotent stem cells: applications in regenerative medicine, disease modeling, and drug discovery. Front Cell Dev Biol. 2015;3:2.

34. Rony IK, Baten A, Bloomfield JA, Islam ME, Billah MM, Islam KD. Inducing pluripotency in vitro: recent advances and highlights in induced pluripotent stem cells generation and pluripotency reprogramming. Cell Prolif. 2015;48:140-56

35. Li J, Song W, Pan G, Zhou J. Advances in understanding the cell types and approaches used for generating induced pluripotent stem cells. J Hematol Oncol. 2014;7:50

36. Zhou YY, Zeng F. Integration-free methods for generating induced pluripotent stem cells. Genomics Proteomics Bioinformatics. 2013;11:284-7.

37. Petit I, Kesner NS, Karry R, Robicsek O, Aberdam E, Muller FJ, et al. Induced pluripotent stem cells from hair follicles as a cellular model for neurodevelopmental disorders. Stem Cell Res. 2012:8:134-40.

38. Raab S, Klingenstein M, Liebau S, Linta L. A Comparative View on Human Somatic Cell Sources for iPSC Generation. Stem Cells Int. 2014;2014:768391.

39. Lord C, Rutter M, Goode S, Heemsbergen J, Jordan H, Mawhood L, et al. Autism diagnostic observation schedule: a standardized observation of communicative and social behavior. J Autism Dev Disord. 1989;19:185-212.

40. Lord C, Rutter M, Le Couteur A. Autism Diagnostic Interview-Revised: a revised version of a diagnostic interview for caregivers of individuals with possible pervasive developmental disorders. J Autism Dev Disord. 1994:24:659-85.

41. Guy W. ECDEU Assessment Manual for Psychopharmacology. Rockville, Md US Department of Health, Education, and Welfare; 1976.

42. Schopler E, Reichler RJ, DeVellis RF, Daly K. Toward objective classification of childhood autism: Childhood Autism Rating Scale (CARS). J Autism Dev Disord. 1980;10:91-103

43. Mayes SD, Calhoun SL, Murray MJ, Morrow JD, Yurich KKL, Cothren S, et al. Use of the Childhood Autism Rating Scale (CARS) for Children With High Functioning Autism or Asperger Syndrome. Focus on Autism and Other Developmental Disabilities. 2012;27:31-8.

44. Krug DA, Arick J, Almond P. Behavior checklist for identifying severely handicapped individuals with high levels of autistic behavior. J Child Psychol Psychiatry. 1980;21:221-9.

45. Volkmar FR, Cicchetti DV, Dykens E, Sparrow SS, Leckman JF, Cohen DJ. An evaluation of the Autism Behavior Checklist. J Autism Dev Disord. 1988;18:81-97.

46. Constantino J. The social responsiveness scale. Los Angeles: Western Psychological Services; 2002.

47. Aldridge FJ, Gibbs VM, Schmidhofer K, Williams M. Investigating the clinical usefulness of the Social Responsiveness Scale (SRS) in a tertiary level, autism spectrum disorder specific assessment clinic. J Autism Dev Disord. 2012:42:294-300

48. Wechsler D. The Measurement of Adult Intelligence. Baltimore: Williams \& Wilkins; 1939

49. Dowey SN, Huang X, Chou BK, Ye Z, Cheng L. Generation of integration-free human induced pluripotent stem cells from postnatal blood mononuclear cells by plasmid vector expression. Nat Protoc. 2012;7:2013-21.
50. Quintana-Bustamante O, Segovia JC. Generation of Patient-Specific induced Pluripotent Stem Cell from Peripheral Blood Mononuclear Cells by Sendai Reprogramming Vectors. Clifton, N.J: Methods in molecular biology; 2014.

51. Yu J, Vodyanik MA, Smuga-Otto K, Antosiewicz-Bourget J, Frane JL, Tian S, et al. Induced pluripotent stem cell lines derived from human somatic cells. Science (New York, NY). 2007;318:1917-20.

52. Maherali N, Hochedlinger K. Guidelines and techniques for the generation of induced pluripotent stem cells. Cell Stem Cell. 2008;3:595-605.

53. Nori S, Okada Y, Nishimura S, Sasaki T, Itakura G, Kobayashi Y, et al. Longterm safety issues of iPSC-based cell therapy in a spinal cord injury model: oncogenic transformation with epithelial-mesenchymal transition. Stem Cell Rep. 2015;4:360-73.

54. Choi HW, Kim JS, Choi S, Hong YJ, Kim MJ, Seo HG, et al. Neural stem cells differentiated from iPS cells spontaneously regain pluripotency. Stem cells (Dayton, Ohio). 2014;32:2596-604

55. Fusaki N, Ban H, Nishiyama A, Saeki K, Hasegawa M. Efficient induction of transgene-free human pluripotent stem cells using a vector based on Sendai virus, an RNA virus that does not integrate into the host genome. Proc Jpn Acad Ser B Phys Biol Sci. 2009;85:348-62.

56. Stadtfeld M, Nagaya M, Utikal J, Weir G, Hochedlinger K. Induced pluripotent stem cells generated without viral integration. Science (New York, NY). 2008;322:945-9.

57. Okita K, Nakagawa M, Hyenjong H, Ichisaka T, Yamanaka S. Generation of mouse induced pluripotent stem cells without viral vectors. Science (New York, NY). 2008;322:949-53.

58. Somers A, Jean JC, Sommer CA, Omari A, Ford CC, Mills JA, et al. Generation of transgene-free lung disease-specific human induced pluripotent stem cells using a single excisable lentiviral stem cell cassette. Stem cells (Dayton, Ohio). 2010;28:1728-40.

59. Woltjen K, Michael IP, Mohseni P, Desai R, Mileikovsky M, Hamalainen R, et al. piggyBac transposition reprograms fibroblasts to induced pluripotent stem cells. Nature. 2009:458:766-70.

60. Kim D, Kim CH, Moon Jl, Chung YG, Chang MY, Han BS, et al. Generation of human induced pluripotent stem cells by direct delivery of reprogramming proteins. Cell Stem Cell. 2009;4:472-6.

61. Warren L, Manos PD, Ahfeldt T, Loh YH, Li H, Lau F, et al. Highly efficient reprogramming to pluripotency and directed differentiation of human cells with synthetic modified mRNA. Cell Stem Cell. 2010;7:618-30.

62. Dang J, Rana TM. Enhancing Induced Pluripotent Stem Cell Generation by MicroRNA. Clifton, N.J: Methods in molecular biology; 2015.

63. Yoshioka N, Gros E, Li HR, Kumar S, Deacon DC, Maron C, et al. Efficient generation of human iPSCs by a synthetic self-replicative RNA. Cell Stem Cell. 2013;13:246-54

64. Woodard LE, Wilson MH. piggyBac-ing models and new therapeutic strategies. Trends Biotechnol. 2015;33:525-33.

65. Lin T, Wu S. Reprogramming with Small Molecules instead of Exogenous Transcription Factors. Stem Cells Int. 2015;2015:794632.

66. Ban H, Nishishita N, Fusaki N, Tabata T, Saeki K, Shikamura M, et al. Efficient generation of transgene-free human induced pluripotent stem cells (iPSCS) by temperature-sensitive Sendai virus vectors. Proc Natl Acad Sci U S A. 2011:108:14234-9.

67. Fujie Y, Fusaki N, Katayama T, Hamasaki M, Soejima Y, Soga M, et al. New type of Sendai virus vector provides transgene-free iPS cells derived from chimpanzee blood. PLoS One. 2014;9:e113052.

68. Zhou W, Freed CR. Adenoviral gene delivery can reprogram human fibroblasts to induced pluripotent stem cells. Stem cells (Dayton, Ohio) 2009:27:2667-74.

69. Okita K, Matsumura Y, Sato Y, Okada A, Morizane A, Okamoto S, et al. A more efficient method to generate integration-free human iPS cells. Nat Methods. 2011:8:409-12.

70. Kaji K, Norrby K, Paca A, Mileikovsky M, Mohseni P, Woltjen K. Virus-free induction of pluripotency and subsequent excision of reprogramming factors. Nature. 2009;458:771-5.

71. Chang CW, Lai YS, Pawlik KM, Liu K, Sun CW, Li C, et al. Polycistronic lentiviral vector for "hit and run" reprogramming of adult skin fibroblasts to induced pluripotent stem cells. Stem cells (Dayton, Ohio). 2009;27:1042-9.

72. Ren X, Tahimic CG, Katoh M, Kurimasa A, Inoue T, Oshimura M. Human artificial chromosome vectors meet stem cells: new prospects for gene delivery. Stem Cell Rev. 2006;2:43-50.

73. Jia F, Wilson KD, Sun N, Gupta DM, Huang M, Li Z, et al. A nonviral minicircle vector for deriving human iPS cells. Nat Methods. 2010;7:197-9. 
74. Hiratsuka M, Uno N, Ueda K, Kurosaki H, Imaoka N, Kazuki K, et al. Integration-free iPS cells engineered using human artificial chromosome vectors. PLoS One. 2011;6:e25961

75. Narsinh KH, Jia F, Robbins RC, Kay MA, Longaker MT, Wu JC. Generation of adult human induced pluripotent stem cells using nonviral minicircle DNA vectors. Nat Protoc. 2011;6:78-88.

76. Malik N, Rao MS. A review of the methods for human iPSC derivation. Methods in molecular biology (Clifton, NJ). 2013;997:23-33.

77. Huangfu D, Maehr R, Guo W, Eijkelenboom A, Snitow M, Chen AE, et al. Induction of pluripotent stem cells by defined factors is greatly improved by small-molecule compounds. Nat Biotechnol. 2008;26:795-7.

78. Huangfu D, Osafune K, Maehr R, Guo W, Eijkelenboom A, Chen S, et al. Induction of pluripotent stem cells from primary human fibroblasts with only Oct4 and Sox2. Nat Biotechnol. 2008;26:1269-75.

79. Li W, Zhou H, Abujarour R, Zhu S, Young Joo J, Lin T, et al. Generation of human-induced pluripotent stem cells in the absence of exogenous Sox2. Stem cells (Dayton, Ohio). 2009;27:2992-3000.

80. Hou P, Li Y, Zhang X, Liu C, Guan J, Li H, et al. Pluripotent stem cells induced from mouse somatic cells by small-molecule compounds. Science (New York, NY). 2013;341:651-4

81. Schlaeger TM, Daheron L, Brickler TR, Entwisle S, Chan K, Cianci A, et al. A comparison of non-integrating reprogramming methods. Nat Biotechnol. 2015;33:58-63.

82. Gaspard N, Vanderhaeghen P. Mechanisms of neural specification from embryonic stem cells. Curr Opin Neurobiol. 2010;20:37-43.

83. Perrier AL, Tabar V, Barberi T, Rubio ME, Bruses J, Topf N, et al. Derivation of midbrain dopamine neurons from human embryonic stem cells. Proc Natl Acad Sci U S A. 2004;101:12543-8.

84. Lee SH, Lumelsky N, Studer L, Auerbach JM, McKay RD. Efficient generation of midbrain and hindbrain neurons from mouse embryonic stem cells. Nat Biotechnol. 2000;18:675-9.

85. Wichterle H, Lieberam I, Porter JA, Jessell TM. Directed differentiation of embryonic stem cells into motor neurons. Cell. 2002;110:385-97.

86. Li XJ, Du ZW, Zarnowska ED, Pankratz M, Hansen LO, Pearce RA, et al. Specification of motoneurons from human embryonic stem cells. Nat Biotechnol. 2005;23:215-21

87. Zhang SC, Wernig M, Duncan ID, Brustle O, Thomson JA. In vitro differentiation of transplantable neural precursors from human embryonic stem cells. Nat Biotechnol. 2001;19:1129-33.

88. Okabe S, Forsberg-Nilsson K, Spiro AC, Segal M, McKay RD. Development of neuronal precursor cells and functional postmitotic neurons from embryonic stem cells in vitro. Mech Dev. 1996;59:89-102.

89. Imaizumi Y, Okada Y, Akamatsu W, Koike M, Kuzumaki N, Hayakawa H, et al. Mitochondrial dysfunction associated with increased oxidative stress and alpha-synuclein accumulation in PARK2 iPSC-derived neurons and postmortem brain tissue. Mol Brain. 2012;5:35.

90. Numasawa-Kuroiwa Y, Okada Y, Shibata S, Kishi N, Akamatsu W, Shoji M. Involvement of ER stress in dysmyelination of Pelizaeus-Merzbacher Disease with PLP1 missense mutations shown by iPSC-derived oligodendrocytes. Stem Cell Rep. 2014;2:648-61.

91. Barberi T, Klivenyi P, Calingasan NY, Lee H, Kawamata H, Loonam K, et al. Neural subtype specification of fertilization and nuclear transfer embryonic stem cells and application in parkinsonian mice. Nat Biotechnol. 2003;21:1200-7.

92. Kawasaki H, Mizuseki K, Nishikawa S, Kaneko S, Kuwana Y, Nakanishi S, et al. Induction of midbrain dopaminergic neurons from ES cells by stromal cell-derived inducing activity. Neuron. 2000;28:31-40.

93. Vierbuchen T, Ostermeier A, Pang ZP, Kokubu Y, Sudhof TC, Wernig M. Direct conversion of fibroblasts to functional neurons by defined factors. Nature. 2010;463:1035-41.

94. Pang ZP, Yang N, Vierbuchen T, Ostermeier A, Fuentes DR, Yang TQ, et al. Induction of human neuronal cells by defined transcription factors. Nature. 2011;476:220-3.

95. Ambasudhan R, Talantova M, Coleman R, Yuan X, Zhu S, Lipton SA, et al. Direct reprogramming of adult human fibroblasts to functional neurons under defined conditions. Cell Stem Cell. 2011;9:113-8.

96. Yoo AS, Sun AX, Li L, Shcheglovitov A, Portmann T, Li Y, et al. MicroRNAmediated conversion of human fibroblasts to neurons. Nature. 2011:476:228-31.

97. Zhang Y, Pak C, Han Y, Ahlenius H, Zhang Z, Chanda S, et al. Rapid singlestep induction of functional neurons from human pluripotent stem cells. Neuron. 2013;78:785-98.
98. Babos K, Ichida JK. Small Molecules Take a Big Step by Converting Fibroblasts into Neurons. Cell Stem Cell. 2015;17:127-9.

99. Li X, Zuo X, Jing J, Ma Y, Wang J, Liu D, et al. Small-Molecule-Driven Direct Reprogramming of Mouse Fibroblasts into Functional Neurons. Cell Stem Cell. 2015;17:195-203.

100. Hu W, Qiu B, Guan W, Wang Q, Wang M, Li W, et al. Direct Conversion of Normal and Alzheimer's Disease Human Fibroblasts into Neuronal Cells by Small Molecules. Cell Stem Cell. 2015;17:204-12.

101. Nguyen HN, Byers B, Cord B, Shcheglovitov A, Byrne J, Gujar P, et al. LRRK2 mutant iPSC-derived DA neurons demonstrate increased susceptibility to oxidative stress. Cell Stem Cell. 2011;8:267-80.

102. Seibler P, Graziotto J, Jeong H, Simunovic F, Klein C, Krainc D. Mitochondrial Parkin recruitment is impaired in neurons derived from mutant PINK1 induced pluripotent stem cells. The Journal of neuroscience : the official journal of the Society for Neuroscience. 2011;31:5970-6.

103. Bain G, Kitchens D, Yao M, Huettner JE, Gottlieb DI. Embryonic stem cells express neuronal properties in vitro. Dev Biol. 1995;168:342-57.

104. Marchetto MC, Carromeu C, Acab A, Yu D, Yeo GW, Mu Y, et al. A model for neural development and treatment of Rett syndrome using human induced pluripotent stem cells. Cell. 2010;143:527-39.

105. Cheung AY, Horvath LM, Grafodatskaya D, Pasceri P, Weksberg R, Hotta A, et al. Isolation of MECP2-null Rett Syndrome patient hiPS cells and isogenic controls through X-chromosome inactivation. Hum Mol Genet. 2011;20:2103-15.

106. Kim KY, Hysolli E, Park IH. Neuronal maturation defect in induced pluripotent stem cells from patients with Rett syndrome. Proc Natl Acad Sci U S A. 2011;108:14169-74.

107. Pasca SP, Portmann T, Voineagu I, Yazawa M, Shcheglovitov A, Pasca AM, et al. Using iPSC-derived neurons to uncover cellular phenotypes associated with Timothy syndrome. Nat Med. 2011;17:1657-62.

108. Krey JF, Pasca SP, Shcheglovitov A, Yazawa M, Schwemberger R, Rasmusson $R$, et al. Timothy syndrome is associated with activity-dependent dendritic retraction in rodent and human neurons. Nat Neurosci. 2013;16:201-9.

109. Sheridan SD, Theriault KM, Reis SA, Zhou F, Madison JM, Daheron L, et al. Epigenetic characterization of the FMR1 gene and aberrant neurodevelopment in human induced pluripotent stem cell models of fragile X syndrome. PLoS One. 2011;6:e26203.

110. Telias M, Segal M, Ben-Yosef D. Neural differentiation of Fragile $X$ human Embryonic Stem Cells reveals abnormal patterns of development despite successful neurogenesis. Dev Biol. 2013;374:32-45.

111. Chamberlain SJ, Chen PF, Ng KY, Bourgois-Rocha F, Lemtiri-Chlieh F, Levine $E S$, et al. Induced pluripotent stem cell models of the genomic imprinting disorders Angelman and Prader-Willi syndromes. Proc Natl Acad Sci U S A. 2010;107:17668-73.

112. Sandoe J, Eggan K. Opportunities and challenges of pluripotent stem cell neurodegenerative disease models. Nat Neurosci. 2013;16:780-9.

113. Han SS, Williams LA, Eggan KC. Constructing and deconstructing stem cell models of neurological disease. Neuron. 2011;70:626-44.

114. Chambers SM, Fasano CA, Papapetrou EP, Tomishima M, Sadelain M, Studer L. Highly efficient neural conversion of human ES and iPS cells by dual inhibition of SMAD signaling. Nat Biotechnol. 2009;27:275-80.

115. Chambers SM, Mica Y, Lee G, Studer L, Tomishima MJ. Dual-SMAD Inhibition/WNT Activation-Based Methods to Induce Neural Crest and Derivatives from Human Pluripotent Stem Cells. Clifton, N.J: Methods in molecular biology; 2013.

116. Pera MF, Andrade J, Houssami S, Reubinoff B, Trounson A, Stanley EG, et al. Regulation of human embryonic stem cell differentiation by BMP-2 and its antagonist noggin. J Cell Sci. 2004;117:1269-80.

117. Shcheglovitov A, Shcheglovitova O, Yazawa M, Portmann T, Shu R, Sebastiano V, et al. SHANK3 and IGF1 restore synaptic deficits in neurons from 22q13 deletion syndrome patients. Nature. 2013;503:267-71.

118. Chanda S, Ang CE, Davila J, Pak C, Mall M, Lee QY, et al. Generation of induced neuronal cells by the single reprogramming factor ASCL1. Stem Cell Rep. 2014;3:282-96.

119. Chanda S, Marro S, Wernig M, Sudhof TC. Neurons generated by direct conversion of fibroblasts reproduce synaptic phenotype caused by autismassociated neuroligin-3 mutation. Proc Natl Acad Sci U S A. 2013;110:16622-7.

120. Yoo AS, Sun AX, Li L, Shcheglovitov A, Portmann T, Li Y, et al. MicroRNAmediated conversion of human fibroblasts to neurons. Nature. 2011;476:228-31.

121. Ladewig J, Mertens J, Kesavan J, Doerr J, Poppe D, Glaue F, et al. Small molecules enable highly efficient neuronal conversion of human fibroblasts. Nat Methods. 2012;9:575-8. 
122. Kim J, Efe JA, Zhu S, Talantova M, Yuan X, Wang S, et al. Direct reprogramming of mouse fibroblasts to neural progenitors. Proc Natl Acad Sci U S A. 2011;108:7838-43.

123. Thier M, Worsdorfer P, Lakes YB, Gorris R, Herms S, Opitz T, et al. Direct conversion of fibroblasts into stably expandable neural stem cells. Cell Stem Cell. 2012;10:473-9.

124. Han DW, Tapia N, Hermann A, Hemmer K, Hoing S, Arauzo-Bravo MJ, et al. Direct reprogramming of fibroblasts into neural stem cells by defined factors. Cell Stem Cell. 2012;10:465-72.

125. Ring KL, Tong LM, Balestra ME, Javier R, Andrews-Zwilling Y, Li G, et al. Direct reprogramming of mouse and human fibroblasts into multipotent neural stem cells with a single factor. Cell Stem Cell. 2012;11:100-9.

126. Kim SM, Flasskamp H, Hermann A, Arauzo-Bravo MJ, Lee SC, Lee SH, et al. Direct conversion of mouse fibroblasts into induced neural stem cells. Nat Protoc. 2014;9:871-81.

127. Just MA, Cherkassky VL, Keller TA, Kana RK, Minshew NJ. Functional and anatomical cortical underconnectivity in autism: evidence from an FMRI study of an executive function task and corpus callosum morphometry. Cerebral cortex (New York, NY : 1991). 2007;17:951-61.

128. Brennand KJ, Gage FH. Modeling psychiatric disorders through reprogramming. Dis Model Mech. 2012;5:26-32.

129. Amaral DG, Schumann CM, Nordahl CW. Neuroanatomy of autism. Trends Neurosci. 2008;31:137-45.

130. Lancaster MA, Renner M, Martin CA, Wenzel D, Bicknell LS, Hurles ME, et al. Cerebral organoids model human brain development and microcephaly. Nature. 2013;501:373-9.

131. Lancaster MA, Knoblich JA. Generation of cerebral organoids from human pluripotent stem cells. Nat Protoc. 2014;9:2329-40.

132. Mariani J, Coppola G, Zhang P, Abyzov A, Provini L, Tomasini L, et al. FOXG1-Dependent Dysregulation of GABA/Glutamate Neuron Differentiation in Autism Spectrum Disorders. Cell. 2015;162:375-90.

133. Farra N, Zhang WB, Pasceri P, Eubanks JH, Salter MW, Ellis J. Rett syndrome induced pluripotent stem cell-derived neurons reveal novel neurophysiological alterations. Mol Psychiatry. 2012;17:1261-71.

134. Urbach A, Bar-Nur O, Daley GQ, Benvenisty N. Differential modeling of fragile $X$ syndrome by human embryonic stem cells and induced pluripotent stem cells. Cell Stem Cell. 2010;6:407-11.

135. Mullen RJ, Buck CR, Smith AM. NeuN, a neuronal specific nuclear protein in vertebrates. Development. 1992;116:201-11.

136. Bonfanti L, Theodosis DT. Expression of polysialylated neural cell adhesion molecule by proliferating cells in the subependymal layer of the adult rat, in its rostral extension and in the olfactory bulb. Neuroscience. 1994;62:291-305.

137. von Bohlen Und Halbach O. Immunohistological markers for staging neurogenesis in adult hippocampus. Cell Tissue Res. 2007:329:409-20.

138. Takamori S, Rhee JS, Rosenmund C, Jahn R. Identification of a vesicular glutamate transporter that defines a glutamatergic phenotype in neurons. Nature. 2000;407:189-94.

139. Kaufman DL, Houser CR, Tobin AJ. Two forms of the gamma-aminobutyric acid synthetic enzyme glutamate decarboxylase have distinct intraneuronal distributions and cofactor interactions. J Neurochem. 1991;56:720-3.

140. Pickel VM, Joh TH, Field PM, Becker CG, Reis DJ. Cellular localization of tyrosine hydroxylase by immunohistochemistry. The journal of histochemistry and cytochemistry : official journal of the Histochemistry Society. 1975;23:1-12.

141. Frantz GD, Weimann JM, Levin ME, McConnell SK. Otx1 and Otx2 define layers and regions in developing cerebral cortex and cerebellum. The Journal of neuroscience : the official journal of the Society for Neuroscience. 1994;14:5725-40.

142. Weimann JM, Zhang YA, Levin ME, Devine WP, Brulet P, McConnell SK Cortical neurons require Otx 1 for the refinement of exuberant axonal projections to subcortical targets. Neuron. 1999;24:819-31.

143. Arlotta P, Molyneaux BJ, Chen J, Inoue J, Kominami R, Macklis JD. Neuronal subtype-specific genes that control corticospinal motor neuron development in vivo. Neuron. 2005:45:207-21.

144. Bulfone A, Smiga SM, Shimamura K, Peterson A, Puelles L, Rubenstein JL. Tbrain-1: a homolog of Brachyury whose expression defines molecularly distinct domains within the cerebral cortex. Neuron. 1995;15:63-78.

145. Bedogni F, Hodge RD, Elsen GE, Nelson BR, Daza RA, Beyer RP, et al. Tbr 1 regulates regional and laminar identity of postmitotic neurons in developing neocortex. Proc Natl Acad Sci U S A. 2010;107:13129-34.

146. Nieto M, Monuki ES, Tang H, Imitola J, Haubst N, Khoury SJ, et al. Expression of Cux-1 and Cux-2 in the subventricular zone and upper layers II-IV of the cerebral cortex. J Comp Neurol. 2004;479:168-80.
147. Alcamo EA, Chirivella L, Dautzenberg M, Dobreva G, Farinas I, Grosschedl R, et al. Satb2 regulates callosal projection neuron identity in the developing cerebral cortex. Neuron. 2008;57:364-77.

148. Britanova O, de Juan Romero C, Cheung A, Kwan KY, Schwark M, Gyorgy A, et al. Satb2 is a postmitotic determinant for upper-layer neuron specification in the neocortex. Neuron. 2008:57:378-92.

149. Tian Y, Voineagu I, Pasca SP, Won H, Chandran V, Horvath S, et al. Alteration in basal and depolarization induced transcriptional network in iPSC derived neurons from Timothy syndrome. Genome Med. 2014;6:75.

150. Germain ND, Chen PF, Plocik AM, Glatt-Deeley H, Brown J, Fink JJ, et al. Gene expression analysis of human induced pluripotent stem cell-derived neurons carrying copy number variants of chromosome 15q11-q13.1. Mol Autism. 2014;5:44.

151. Ananiev G, Williams EC, Li H, Chang Q. Isogenic pairs of wild type and mutant induced pluripotent stem cell (iPSC) lines from Rett syndrome patients as in vitro disease model. PLoS One. 2011;6:e25255.

152. Andoh-Noda T, Akamatsu W, Miyake K, Matsumoto T, Yamaguchi R, Sanosaka T, et al. Differentiation of multipotent neural stem cells derived from Rett syndrome patients is biased toward the astrocytic lineage. Mol Brain. 2015:8:31.

153. Tropea D, Giacometti E, Wilson NR, Beard C, McCurry C, Fu DD, et al. Partial reversal of Rett Syndrome-like symptoms in MeCP2 mutant mice. Proc Natl Acad Sci U S A. 2009;106:2029-34

154. Griesi-Oliveira K, Acab A, Gupta AR, Sunaga DY, Chailangkarn T, Nicol X, et al. Modeling non-syndromic autism and the impact of TRPC 6 disruption in human neurons. Mol Psychiatry. 2014;20:361-8.

155. Panopoulos AD, Ruiz S, Izpisua Belmonte JC. iPSCs: induced back to controversy. Cell Stem Cell. 2011;8:347-8.

156. Cao S, Loh K, Pei Y, Zhang W, Han J. Overcoming barriers to the clinical utilization of iPSCs: reprogramming efficiency, safety and quality. Protein Cell. 2012;3:834-45.

157. Paull D, Sevilla A, Zhou H, Hahn AK, Kim H, Napolitano C, et al. Automated high-throughput derivation, characterization and differentiation of induced pluripotent stem cells. Nat Methods. 2015;12:885-92.

158. Bock C, Kiskinis E, Verstappen G, Gu H, Boulting G, Smith ZD, et al. Reference Maps of human ES and iPS cell variation enable high-throughput characterization of pluripotent cell lines. Cell. 2011;144:439-52.

159. Dajani R, Koo SE, Sullivan GJ, Park $\mid H$. Investigation of Rett syndrome using pluripotent stem cells. J Cell Biochem. 2013;114:2446-53.

160. Osafune K, Caron L, Borowiak M, Martinez RJ, Fitz-Gerald CS, Sato Y, et al. Marked differences in differentiation propensity among human embryonic stem cell lines. Nat Biotechnol. 2008:26:313-5.

161. Gore A, Li Z, Fung HL, Young JE, Agarwal S, Antosiewicz-Bourget J, et al. Somatic coding mutations in human induced pluripotent stem cells. Nature. 2011;471:63-7

162. Hussein SM, Batada NN, Vuoristo S, Ching RW, Autio R, Narva E, et al. Copy number variation and selection during reprogramming to pluripotency. Nature. 2011;471:58-62.

163. Tong $M, L v Z$, Liu L, Zhu H, Zheng QY, Zhao XY, et al. Mice generated from tetraploid complementation competent iPS cells show similar developmental features as those from ES cells but are prone to tumorigenesis. Cell Res. 2011;21:1634-7.

164. Hu BY, Weick JP, Yu J, Ma LX, Zhang XQ, Thomson JA, et al. Neural differentiation of human induced pluripotent stem cells follows developmental principles but with variable potency. Proc Natl Acad Sci U S A. 2010;107:4335-40.

165. Srikanth P, Young-Pearse TL. Stem cells on the brain: modeling neurodevelopmental and neurodegenerative diseases using human induced pluripotent stem cells. J Neurogenet. 2014;28:5-29.

166. Li Y, Wang H, Muffat J, Cheng AW, Orlando DA, Loven J, et al. Global transcriptional and translational repression in human-embryonic-stemcell-derived Rett syndrome neurons. Cell Stem Cell. 2013;13:446-58.

167. Bershteyn M, Kriegstein AR. Cerebral Organoids in a Dish: Progress and Prospects. Cell. 2013;155:19-20.

168. Yu J, Hu K, Smuga-Otto K, Tian S, Stewart R, Slukvin II, et al. Human induced pluripotent stem cells free of vector and transgene sequences. Science (New York, NY). 2009;324:797-801.

169. Soldner F, Laganiere J, Cheng AW, Hockemeyer D, Gao Q, Alagappan R, et al. Generation of isogenic pluripotent stem cells differing exclusively at two early onset Parkinson point mutations. Cell. 2011;146:318-31. 
170. Papapetrou EP, Sadelain M. Generation of transgene-free human induced pluripotent stem cells with an excisable single polycistronic vector. Nat Protoc. 2011;6:1251-73.

171. Zhou H, Wu S, Joo JY, Zhu S, Han DW, Lin T, et al. Generation of induced pluripotent stem cells using recombinant proteins. Cell Stem Cell. 2009;4:381-4.

Submit your next manuscript to BioMed Central and take full advantage of:

- Convenient online submission

- Thorough peer review

- No space constraints or color figure charges

- Immediate publication on acceptance

- Inclusion in PubMed, CAS, Scopus and Google Scholar

- Research which is freely available for redistribution 